\title{
The Establishment of National Hospital Insurance Fund and Its Performance, 1966-1972
}

\author{
Joyce Chepkwony
}

\begin{abstract}
Establishment of National Hospital Insurance Fund and its Performance in Kenya in the period between 1966 and 1972. An elaboration of factors which facilitated its establishment, management, administration and amendments to the entity are undertaken to assess its significance in this period. Literature review was through an assessment of various sources relevant in the establishment of NHIF as a non-racial scheme, the NHIF Board of Management, Administration and Amendments, which were important in evaluating the Performance of NHIF during the period of examination. This assessment provides the dynamics which impacted on NHIF service delivery in the period, 1966-1972. The study utilised the Political Economy perspective to analyse the establishment of the NHIF and the factors which impacted on the performance of the healthcare service provider from 1966 to 1972 . The historical method guided the study to discover from records and other accounts the underlying factors that impacted on the performance of the NHIF in the period of examination. The study found out that the NHIF was established as part of the Kenya government development agenda to enhance the welfare of its citizens and therefore, achieve socio-economic progress. The study also established that there was the formation of a Board of Management for the NHIF, which was tasked with administration and implementation of significant amendments to the healthcare service provider. Further, the study found out that government policies in this period were shaped by the global events and subsequently, the financing capacities in the socio-economic sectors. The study also established that there were numerous amendments on the NHIF Act, which shaped the modes of service delivery in this period. This article concludes that the dynamics experienced by the NHIF in this period were relevant in enhancing service delivery for the citizens in the subsequent decades.
\end{abstract}

Index Terms - Accreditation, Advisory Council, Compulsory Contribution, Financing scheme, Health policy, Hospital benefits, NHIF, NHIF Act, Non-Racial Scheme, Service Delivery, Voluntary Scheme

\section{BACKGROUND}

This article assesses the Establishment of the NHIF and Its Performance in the period 1966 - 1972. The independent government formulated policies relevant in the formation of a non-racial health insurance scheme, the National Health Insurance Scheme (NHIS) to facilitate access to healthcare services by the citizens. ${ }^{[1][2]}$ The formation of an Advisory Council was essential in the formulation of financial changes affecting the management of the healthcare service provider.

Joyce Chepkwony, Department of Philosophy, History and Religion, Egerton University, Nakuru, Great Lakes University of Kisumu, Kenya
For instance, the Council was significant in recommending policy review to allow increase of hospital benefits accessible to contributors, rather than the reduction of the minimum income to contribute to the scheme. There were also other reviews on benefits to dependants, pricing of services and the limit of benefits to the contributors. ${ }^{[2][4]}$ The performance of the NHIF in this period was gauged through the establishment of a Board of Management to facilitate the amendments and administer, which were essential in improving service delivery. The NHIS Board as it was before the renaming of the entity to NHIF, was constituted under section 25 of the NHIS Act of 1965, with membership drawn from the Ministries of Health, Finance and Labour appointees. ${ }^{[3]}$ Other members were also derived from the Federation of Kenya Employers (FKE), Kenya National Union of Teachers (KNUT), the Central Organisation of Trade Unions (COTU), private and mission hospitals as well as commerce, industry and the farming sectors. The Board was therefore, responsible for numerous managerial activities significant in the administration of the healthcare service provider. ${ }^{[5]}$ Additionally, the Board was responsible for reviewing the performance of the service provider to institute amendments essential in improving access to healthcare services. ${ }^{[4]}$

The study also evaluated the performance of NHIF under the global upheavals of the 1970s. The NHIF's operation in this period involved financial deregulation and re-orientation of economies in service delivery. ${ }^{[1]}$ These dynamics, therefore, facilitated the adoption of other financing schemes in the Health Ministry, comprising of general taxes, household private spending as well as the for-profit and the not-for-profit institutions. ${ }^{[40]}$ The government extended the "free healthcare for all" policy to public healthcare facilities in urban and rural settings. Further, decentralisation of the healthcare sector was through external development partners, such as International Monetary Fund (IMF) and World Health Organisation (WHO) to increase the financial resources and thus enhance service delivery aimed at improving access by the populace. ${ }^{[25]}$

Amendments to the NHIF Act (cap.255) were implemented in 1972 by the government through the Health Ministry to 
improve service delivery. These amendments were legally established in 1972 in the various sub sections of the 1967 NHIF Act. For instance, amendment on section 5, sub section 3 would provide for the reduction of the minimum income at which liability commences, computed on a monthly income of KSh.800 or KSh.9 600 as an annual income. ${ }^{25} 28$ Similarly, sub section 8 was amended to exempt married women from contributing to the scheme. Further amendments to the Act were in section 11 to allow for use of computerised recordings, instead of manual register, which was prone to fraud attributed to interferences from staff at the healthcare facilities and the NHIF offices. ${ }^{[26]}$ These amendments among others, were significant in improving quality of services to the beneficiaries, reduce instances of resource pilferage and thus enhance accountability and transparency for service delivery. Hence, the amendments were assented to by the president as the NHIF Amendment Act Number 4 of 1972, effective 1 July $1972 .{ }^{[30]}$

\section{METHODS}

\section{a. Study Approach}

This study adopted the historical method, to discover from records and other accounts what happened in the past period. The ex-post facto design was used in this study, to examine the record of past events and explain why they so happened. The design entails gathering of information from archival documents and oral interviews, which are then subjected to internal and external criticism. Other sources of information for the study included peer-reviewed publications and grey literature on the NHIF since 1966.

Archival information was obtained from documents in the Kenya National Archives (KNA) from files in the Ministry of Health, annual reports, memoranda, articles, journals, policy documents, such as the African Research Foundation Survey of Health Policy in Kenya, African Socialism and its Application in Kenya, Insurance and Compensation Schemes, National Hospital Insurance Advisory Council as well as the Legislations, Acts and National Health Services Act. This review was aimed at establishing the factors that influenced the formation of the NHIF and its performance in the formative period.

Oral interviews were also conducted on previous and current office holders of the NHIF at the headquarters and regional offices. Similarly, the beneficiaries of NHIF since independence to the contemporary period were also interviewed.

\section{b. Analytical Framework}

This article adopted the Political Economy perspective to evaluate the context for the Establishment of the NHIF and its Performance, 1966-1972. The significance of this perspective was on its analysis of how power and resources are distributed and contested in different contexts as well as its implications for development outcomes. ${ }^{[31] ~[32] ~ T h e ~}$ Political Economy perspective demonstrates that economic interests are significant in defining political agenda, which result in the rise of interests within the production system. ${ }^{[34]}$

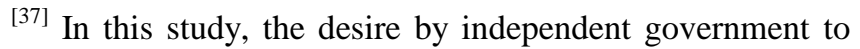
achieve socio-economic development was evident in the formulation of policies to steer the government's development agenda. Hence, the adoption of "African Socialism and its Application in Kenya" in 1965 was part of the goals of enhancing community welfare, which resulted in the establishment of NHIF in 1966. [1] [2] [4] This establishment therefore, was constituted as part of the political agenda, which championed the rise of class interests, within the various forms of production in the formal and informal set ups, such as administration, agriculture, health, education, commerce and industry. ${ }^{[37]}$ Therefore, improving the health systems was a form of legislation that was utilised to facilitate legitimisation of the social order to counter dissatisfaction with the political order. Politics, therefore, offered an alternative to what the market could not provide. ${ }^{[35][36]}$

The Political Economy perspective was relevant to this study as it identified the formal structures that the independent government derived from policy decisions, which resulted in the establishment of NHIF, aimed at reducing the financial barriers that hindered access to affordable healthcare services, thus creating social inequalities. ${ }^{[1][4]}$ Additionally, the socio-economic progress was aimed at achieving equity implications through the implementation a scheme, beneficial to the government and the populace. ${ }^{[2][36]}$

\section{RESUlTS}

This study evaluated the Establishment of the NHIF and its Performance in the period 1966 - 1972 and found out that there were numerous factors that influenced its service delivery in this period. These were discussed as follows;

a) The Establishment of NHIF as a Non-Racial Scheme The NHIF was established following the formulation by the government of the 1964 - 1970 health policy. This programme was based on the realisation that human health was significant in the development of the socio-economic sector. ${ }^{14}$ Further, the government intended to achieve economic progress and was motivated to expand the healthcare sector to enhance access by the populace. Hence, from 1965, the government pursued this agenda through the implementation of various measures. There was for instance, the adoption of the development blue print, Sessional Paper Number 10 of 1965 on "African Socialism and its Application to Kenya." " This policy document was 
significant as it formed part of the mechanisms of alleviating poverty, which was attributed to resource discrepancy in colonial Kenya. Ill health therefore, entrenched poverty as private financing for healthcare was the norm among the populace. $^{[2][36]}$

To alleviate disease and therefore poverty, the government based on policy formulation for Sessional Paper Number 10 abolished the use of out-of-pocket-spending (OOPS) for healthcare services in public facilities. This move was geared towards enhancing access to healthcare services, making it affordable and therefore, reduce inequalities among the populace. ${ }^{[3[10}$

The NHIF was established in 1966 by an Act of Parliament cap.255 to be a financing mechanism that incorporates the formally employed to contribute to the scheme through statutory deductions from the employers. ${ }^{[5]}{ }^{[6]}$ It was established as a corporate body with perpetual succession, empowered to sue and be sued in its corporate name. The Fund was to incorporate all individuals of 18 years and over with a monthly income of KSh.1 000 or over to contribute to the scheme through affixing of a stamp to the NHIF card, worth KSh.40 in accordance to section 5 of the NHIF Act. The contributor to the Fund enjoyed hospital benefits for in-patient utilisation, which included a daily allowance. ${ }^{[4][5]}$ To enhance service delivery of the NHIF, an Advisory Council under section 25 of the NHIF Act was established on 19 December 1966 to provide guidance on management and financial feasibility of the scheme, significant for socio-economic progress. ${ }^{[3]}{ }^{[7]}$ This was to be realised through the expansion of the mandate of the NHIF to enable the provision of a comprehensive health insurance financing mechanism. The aim was the incorporation of individuals in the informal sector to contribute to the scheme on a voluntary basis. This proposed expansion was essential in bridging the discrepancy between the salaried and non-salaried sections of the populations. ${ }^{[5][6]}$

The Advisory Council was also relevant in the formulation of changes for the financial management of the Fund. This entailed the amalgamation of compulsory and voluntary contributory schemes, aimed at improving accountability for financial resources. ${ }^{[11]}$ There were also changes in the contributions from whose remittances were revised downwards from KSh.40 to KSh.20 on the basis of their income, which rarely exceeded KSh.600 in a month. However, they enjoyed similar hospital benefits as the salaried members. ${ }^{[9]}$

b) The NHIS Board if Management, Administration and Amendments
The NHIS Board was constituted under section 25 of the NHIS Act of 1965 and performed numerous functions. Membership to this Board composed of a chairperson appointed by the Health Ministry. There was also an executive director appointed by the NHIS Board who was to be approved by the Health Minister, Principal Secretaries for Health, Finance and Labour. ${ }^{4}$ Similarly, a director of medical services, two representatives each for FKE, KNUT, COTU, private and mission hospitals, commerce, industry and farming sectors were also to be included in the NHIS Board of Management. The executive director also doubled up as the chief executive officer of the NHIF. ${ }^{[3][7]}$

The NHIS Board was also tasked with appointing other members of staff in accordance to the NHIS Act, to carry out the functions of management of the entity. Additionally, the Board consulted with the Finance Ministry to approve or disapprove alterations to contributions by members. ${ }^{[13]}$

The Board in 1965 recommended change of name for the service provider, from NHIS to NHIF as is established under section 28 part $\mathrm{V}$ of the Exchequer and Audit Act. This move was aimed at making the service provider more inclusive for services as well as deal with the financial management of members' contributions. ${ }^{57}$ The term of office for the NHIF Board members was three years, eligible for appointment for another term. The Board was also responsible for rules and regulations governing its meetings. These meetings were constituted by seven members, who deliberated on the Fund's financial management and service provision. ${ }^{[6][11]}$

The minister for Health consulted with the NHIF Board through a gazette notice for accreditation of a hospital, nursing home or maternity to render services in accordance to the NHIF Act. This accreditation was to be in tandem with contributor charges. Similarly, the accredited healthcare service providers were to adhere to charges for services as provided by the Health Ministry. Also, inspection of healthcare facilities by the Directors of NHIF and of Medical Services as well as the Chief Public Health Officer was essential to determine their suitability for accreditation. ${ }^{[4]}{ }^{[8]}$ The NHIF Board stipulated mechanisms of accessing benefits or compensation for medical conditions by the contributors. This was due to the existence of the Workman's Compensation scheme and the NHIF that were accessible to the employed individuals. ${ }^{8}$ Hence, instances of transparency in accessing healthcare was essential to avoid pilferage of the medical care financial resources. This was in accordance to the NHIF Act section 7 part IV, which stipulated the modes of compensation for various injuries and accidents of the insured individuals. ${ }^{914}$

There were also provisions made on exemption of a class of individuals from contributing to the NHIF. For instance, the 
Ministry for Health in consultation with the Board of Management through a gazette notice section 44 of the NHIF Act, exempted all the members of the armed forces (army, navy and air force) with their spouses and children from contributing to the NHIF. ${ }^{2122}$ This exemption was based on the British Voluntary Overseas provision, which excluded them from contributing to the health insurance scheme. Further, members of the armed forces in their terms of service were accessing a complete and comprehensive cover extended to their dependants. ${ }^{18}$

The Board was faced with financial management inefficiencies. In the 1967 NHIF Act, for instance, there was recommendation for stringent measures to seal loopholes which hindered efficient service delivery. There were cases of fraud which were occasioned by forgery of stamps affixed to the contributors' cards and measures to curb losses to the Fund were instituted. [19] [20] Measures included the invocation of section 19(2) (b) of the NHIF Act, which proposed means of dealing with forged stamps presented by the healthcare facilities for reimbursement. ${ }^{[14][20]}$

The loss of revenue to the Fund hindered efficient service delivery. This was occasioned by incompetent hospital inspectors who were not diligent in evaluating healthcare facilities for accreditation. Hence, proposals on reducing revenue losses were to be effected through regular healthcare facility inspections. ${ }^{[17]}$ Additionally, doctors were to be involved in preparation and submission of claims, which detailed illnesses, injuries or accidents sustained and subsequently the accrued medical costs. ${ }^{[20]}$

Other instances of loss of revenue to the government was notable from the employed individuals contributing to the NHIF and NSSF schemes through statutory deductions, but sought healthcare services from private facilities, for in-patient services. These facilities benefited greatly from the compulsory contributors. On the contrary, public healthcare facilities only benefited from maternity rebates from this category of contributors. [15] [16] Subsequently, the government introduced measures aimed at encouraging the utilisation of public healthcare facilities by the NHIF contributors for all disease incidences. This strategy was to enhance the revenue basis for the government. Effective 1 October 1971, for instance, admissions for in-patient services in public healthcare facilities were to be offered at no cost to the compulsory and voluntary NHIF contributors. ${ }^{\text {[23] [24] [38] }}$ The NHIF Amendment Act Number 4 of 1972 was relevant in the introduction of changes to the provisions of the 1966 and 1967 Acts. Key among these amendments was the expansion of compulsory membership to include individuals in the informal sector, whose monthly income exceeded KSh.1 000. ${ }^{[27]}$ Subsequently, the contribution levels were to be raised with the roll out of a graded basis of individuals or employees. Higher benefits were also to be provided, covering more hospital fees and other charges. However, safeguards against arbitrary charges by hospitals were to be effected to authenticate claims by healthcare facilities. ${ }^{[26][40]}$ Additionally, financial modes for reimbursing private healthcare facilities were to be implemented, although checks against abuses were necessary. ${ }^{[24][39]}$ Further, stricter conditions for eligibility to voluntary membership were to be put to place. This was significant in excluding the pre-existing health conditions of a contributor, which were likely to prove a liability to the Fund. ${ }^{[24][42]}$ The Amendment also recommended the abolition of the special and standard contribution under section 5 of the 1966 NHIF Act. This was relevant in streamlining investment clauses to ensure equality in service provision to the citizenry. ${ }^{\text {[23] [27] }}$

c) Performance of the NHIF Amid Global Upheavals

Global upheavals radically influenced political and economic perspectives and therefore, the welfare institutions among nations. These upheavals were as a result of political and economic supremacy of the USA and USSR through their ideologies which were adopted to influence governance and subsequently, financial resource allocation. ${ }^{[25]}{ }^{[32]}$ Populist policies were formulated and implemented in accordance to the ideological inclination of governments. In Kenya, for instance, the establishment of healthcare facilities and infrastructural developments were founded on the achievement of the specific policy guidelines. ${ }^{[25] ~[26] ~[41] ~}$ Hence, the improvement of the welfare institutions and therefore, the establishment of a social health insurance scheme was essential in reducing dependence on family and kin for health needs. The government formulated policies to actualise the provision of "free healthcare" services to the populace. This policy goal was achieved through the adoption of other financing mechanisms aimed at increasing revenue to the sector. ${ }^{[36][39]}$

Gesami attests that the global dynamics of the 1970s resulted in the adoption of numerous financing schemes by the government for the Health Ministry. The schemes adopted formed the basis of the financing arrangements through which citizens accessed healthcare services. ${ }^{[33] ~[36] ~ T h e s e ~}$ schemes also defined how healthcare resources were to be managed and organised and how the resources that enabled the provision of affordable services were to be pooled. Additionally, these schemes involved government general taxes, private household spending and the non-governmental institutions. Further, the government in the 1970s nationalised the health system and thus extended the "Free Healthcare for All" policy, in the publicly managed facilities in urban and rural areas. ${ }^{242538}$ 
The healthcare sector was also decentralised in this period through financial assistance of international fiscal and policy makers, the IMF, WB and WHO to improve efficiency in service delivery. This was through increased financial resource allocation to facilitate infrastructural developments, human resource developments as well as the institution of mechanisms for the establishment of the social health insurance, geared at becoming a sustainable financing model for the citizens. ${ }^{[33]}{ }^{[38]}$

Gesami attributes the improvement of performance of the macro-economic sub sector in the 1970s to high savings and investment ratios as well as the expansion of small-holder cash crop production and favourable external environment. These factors therefore, resulted in the improved healthcare sector due to the enhanced resource allocation, accruing from these sectors. ${ }^{[33][36]}$ Subsequently, growth in the healthcare sector was evident from increased infrastructural developments, rise in numbers enrolled to training institutions and improved living standards of the populace, who were able to spend more on healthcare services than had been previously. This expenditure was linked to health insurance contributions from statutory deductions of the salaried citizenry and the external finances from development partners. ${ }^{[25][41]}$

Mwabu alludes that more priorities were directed towards improving the health status of citizens through increasing financial resources to the sector. This was due to the interdependence of nation's economic development and the health standards of the populace. The nation's economic development therefore, was determined by the health status of the citizenry. ${ }^{[30]}$ [32] [39]

\section{d) Amendments of the NHIF Act (cap.255) of 1972}

The amendments implemented by the Ministry of Health in 1972 targeted the 1967 NHIF Act, to enhance access to service delivery. Several sections of the Act were amended due to the numerous flaws which hindered efficiency. ${ }^{\text {[9] [14] }}$ There were, for instance, amendments to section 5 on its various sub-sections. Sub section III was amended to provide reduction of minimum income at which liability commences on a monthly income of KSh.800 or annually at KSh.9 600 instead of KSh.1 000 or KSh.12 000 as was stated in the 1966 NHIF Act. ${ }^{[15][18]}$

Sub section IV was amended to increase monthly statutory deductions from KSh.20 to KSh.40. Similarly, sub sections V, VI and VII were to be removed from the Act since they dealt with collection of special contributions, which was the responsibility of the Commissioner of Income Tax. ${ }^{\text {[20] [22] }}$ Additionally, sub section VIII of the Act was amended to exempt married women from contributing to the Fund. This amendment was based on NSSF and Income Tax regulations, which exempted women from contributing to the Fund as their spouses were responsible to their dependants. ${ }^{[18][22]}$

Section 5A was also amended to allow for the abolition of voluntary contributions since they had been subjected to abuses by the staff at the Fund and at the accredited healthcare facilities. The abuses comprised of increased number of claims from the voluntary contributors, whose records were not well documented. The amendment was also justified on the basis that normal insurance practice did not recognise the co-existence of the compulsory and voluntary contributions within a scheme. ${ }^{19}{ }^{24}$ However, the incorporation of voluntary contribution had been established owing to the inhibitions of access to healthcare by the non-wage population who utilised out-of-pocket-spending (OOPS) when services were sought. Therefore, this amendment was not implemented due to its significance in healthcare financing, which was characterised by a pre-payment model. ${ }^{\text {[26] [27] }}$

Section 6 of the Act was also amended to compel an employer to remit statutory deductions_from an employee exiting the service to pay the out-standing amounts to the Fund. The amendment was occasioned by losses incurred by the insurer in instances of frequent changes in employment and addresses of the contributors. ${ }^{[28][40]}$

Sections 8 and 9 of the 1967 NHIF Act were also subjected to changes to allow the NHIF Director to set a limit on back payments and penalty demanded from a member with overdue contributions. ${ }^{27}$

Section 10 of the Act was amended to reduce the duration of normal benefits from 180 to 90 days. This adjustment was intended to check special instances which qualified the extension of benefits, by referring to details of treatment from the healthcare service providers. Additionally, amendment in relation to benefits to contributors was to be aligned with quality of services accessed from accredited public healthcare facilities. ${ }^{[26][29]}$ This was attributed to the deteriorating quality of medical services, yet the costs did not commensurate. For instance, costing for such services as $\mathrm{x}$-ray, laboratory evaluations, obstetrics and gynaecology had increased, yet the standards continually deteriorated. It was necessary therefore, to establish a criterion for evaluating a hospital's ability to render services in accordance to the charges for daily allowances. Hence, institution of checks and balances were necessary in safeguarding against the arbitrary increase in costs from accredited healthcare facilities. $^{\text {[27] [30] [36] }}$

The amendment done to allow the use of computerised records was done to section 11 of the Act. This action was prompted by interferences in the manual register by the staff 
at the Fund's offices and the healthcare facilities and had resulted to inaccuracies, fraudulent claims and consequently loss of revenue to the government. ${ }^{[26][39]}$

Amends on section 12 dealt with the value of stamps affixed on the contributor's card. The value of the stamp was to be increased to conform to the new contribution rates of KSh.40 and was to be availed from the NHIF offices rather than from the Ministry of Health. This change was to enhance the processing of claims and therefore improve efficiency in service delivery. ${ }^{\text {[29] [40] }}$

Amending section 26 of the NHIF Act was significant as it was envisaged to increase the earnings from NHIF investments. Further, the investment policy was determined by the Investment Committee of the NHIF Advisory Council, with representatives from the Treasury. The committee advised on the best financial strategies for increasing investments and revenue collection policies. This amendment was aimed at improving service delivery by championing for expanded resource allocation to the healthcare sector. ${ }^{[28][38]}$

Another amendment to the NHIF Act was on section $26 \mathrm{sub}$ section IV, which dealt on claims and benefits in relation to accredited healthcare facilities as well as review of daily charges for services rendered. The approved daily charges for accredited healthcare facilities was KSh.45 for nursing and maternity homes and KSh.55 for a general hospital. ${ }^{\text {[2] [24] [39] }}$ However, refunds to the Fund at a daily rate of KSh.75 if services being sought after by a beneficiary could not be availed from a facility. This move was important in ensuring that accreditation of healthcare facilities for service provision were aligned with available amenities and personnel, which was aimed at reducing inefficiencies stemming from fraud and poor quality of services. The Health Ministry implemented measures, such as cessation of imbursement to facilities that contravened the provisions of the Act. ${ }^{[27][42]}$

The proposed amendments were drafted by the Attorney General and presented to parliament for deliberations and subsequently assented to by the president as the NHIF Amendment Act Number 4 of 1972 and became effective on 1 July 1972. ${ }^{[30] ~[41] ~}$

Table 3.1: Contributions to the NHIF and Benefits by Compulsory Members, 1966-1973

\begin{tabular}{|c|c|c|c|}
\hline Year & $\begin{array}{c}\text { Monthly } \\
\text { Income (KSh.) }\end{array}$ & $\begin{array}{c}\text { Monthly } \\
\text { Contributions } \\
\text { (KSh.) }\end{array}$ & $\begin{array}{c}\text { Daily } \\
\text { Hospital } \\
\text { Benefits } \\
\text { (KSh.) }\end{array}$ \\
\hline 1966 & $>1000$ & 20 & 50 \\
\hline 1973 & $>1000$ & 40 & 80 \\
\hline
\end{tabular}

Source: Republic of Kenya (1973), Central Authority, 1973-1977 Nairobi: Government Printers
Table 3.2: Contributions to the NHIF and Benefits by Voluntary Members, 1966-1973

\begin{tabular}{|c|c|c|c|}
\hline Year & $\begin{array}{c}\text { Monthly Income } \\
\text { KSh.) }\end{array}$ & $\begin{array}{c}\text { Monthly } \\
\text { Contributions } \\
\text { (KSh.) }\end{array}$ & $\begin{array}{c}\text { Daily } \\
\text { Hospital } \\
\text { Benefits } \\
\text { (KSh.) }\end{array}$ \\
\hline 1966 & N/A & N/A & N/A \\
\hline 1973 & 600 & 20 & 35 \\
\hline
\end{tabular}

Source: Republic of Kenya (1973), Central Authority, 1973-1977 Nairobi: Government Printers

Table 3.1 and 3.2 show the changes in the hospital benefits accessible to the NHIF contributors computed from the monthly salary deductions. Notable from these tables is the inclusion of the non-wage contributors to the scheme on a voluntary basis provided their minimum monthly income is KSh.600. Hence, from 1973 they were to make monthly contributions of KSh.20 to the scheme and access daily hospital benefits calculated at KSh.35. Similarly, the monthly contribution to the scheme from the waged population was revised upwards from KSh.20 in 1966 to KSh.40 from 1973. This category of population also accessed daily hospital benefits at KSh.50 in 1966, but was increased to KSh.80 in 1973.

\section{DISCUSSION}

The establishment of the NHIF and its performance in the period 1966-1972 is significant in assessing the government's role in promoting welfare of the citizens. The period under study is relevant in evaluating the challenges that resulted in setbacks and milestones of the NHIF.

This study found out that the Kenya government established NHIF in 1966 as a non-racial health scheme, which was a departure from the colonial system of health care provisions. This establishment was part of the government agenda, for enhancing socio-economic development, based on the 1964-1970 health policy. ${ }^{[1]}$ Hence, as part of achieving this policy, the government in 1965 introduced free medical services in all public healthcare facilities. Further, the provision of "free" healthcare services was in accordance to Sessional Paper Number 10 of 1965 on "African Socialism and its Application in Kenya." The result of the formulation and adoption of these policy statements was the abolition of user fees to enhance access to affordable healthcare services. The significance of provision of free healthcare was a means of addressing resource discrepancies among populations. ${ }^{[2]}$ The NHIF was established as a mandatory financing scheme to facilitate the pooling of resources from the formally employed citizens through statutory deductions to enable them access healthcare services whenever needed and therefore, reduce instances of private financing. Further, the employed citizens were to be enrolled to the scheme when 
they attained the age of eighteen years with an income of KSh.1 000 and above to contribute to the Fund a sum of KSh.40 in a stamp affixed to the card. ${ }^{[3]}$ This contribution enabled a hospital admission with computed daily benefits from hospital treatment charges. The NHIF was to be an efficient service provider with established managerial systems. These included an Advisory Council, established under sections 25 of the NHIF Act and its membership was derived from the Ministries of Health, Treasury, Labour as well as the various hospital representatives. Hence, the Council recommended the expansion of the Fund's mandate to include individuals in the informal sector to contribute on a voluntary basis. ${ }^{[3][8]}$

The study also established that there was the formation of a NHIS Board of Management, which was responsible for the administration of the Fund. Similarly, the Board was tasked with instituting numerous amendments, which were significant for efficient service delivery. Further, this Board of Management was constituted under section 25 of the NHIS Act of 1965. Membership to this Board was drawn from the Ministries of Health, Treasury and Labour. They also included the Directors of Medical Services, two representatives from FKE, KNUT, COTU as well as representatives for commerce, industry and the agricultural sectors. ${ }^{[2]}$ The Board was also tasked with the appointment of staff and stipulating the amount for contributing to the health scheme. Additionally, the Board in 1965 recommended the change of name from NHIS to NHIF, established under section 28 of the Exchequer and Audit Act, aimed at making it more inclusive for services and to deal with financial management of the contributions. ${ }^{5}$ The Board issued notices for inspecting healthcare facilities for accreditation in accordance to the NHIF Act. The accredited healthcare facilities were to operate in accordance to the stipulated charges for hospital services. ${ }^{[4]}$ The Board also had the authority to exempt any class of individuals from the provisions of the Act. Further, the Board was tasked with sealing loopholes resulting from fraudulent claims and caused loss of financial resources. ${ }^{\text {[7] }}$

The study also found out that the global upheavals of the 1970s determined government policy formulation. There were, for instance, populist policies adopted to facilitate the realisation on development agenda, which included mechanisms for reducing dependency on private financing for healthcare services. [23] Further, the financing mechanisms adopted in this period defined management of healthcare resources, which was to be organised through pooling of resources. This was significant in the establishment of a basis of a social health insurance cover. Subsequently, the international fiscal and policy makers, the
$\mathrm{WB}$, the IMF and WHO increased financial obligations, evident in the development and establishment if the NHIF, which was geared at becoming a sustainable financing model for the citizens. [25] [41] Similarly, the improved macro-economic performance in Kenya resulted in improved living standards and thus enabled increased expenditure on healthcare services. This expenditure was evident from the health insurance contributions and OOPS, which were sourced from internal and external financing models. ${ }^{[33][38]}$ This study established that the Amendments to the NHIF Act, cap. 255 of 1972 were significant in improving service delivery. These amendments were revisions to the previous amendments, such as those of 1966, 1967, 1968 and 1969. ${ }^{\text {[9] }}$ ${ }^{[10]}$ These amendments centred on income liability, monthly statutory deductions as well as exemptions on particular interest groups. Amendments were also implemented to streamline compulsory and voluntary contributions. Other changes were necessary in facilitating remittances of statutory deductions from employers to reduce revenue losses to the insurer. ${ }^{[40]}$ Amendments were also essential in the setting of limits on back payments and penalties for overdue payments from members. Changes on duration for accessing hospital benefits were also effected, which reduced from 180 to 90 days. Also, amends on costs for medical services were important to ensure that they were computed according to the quality of services accessible from the healthcare facilities. ${ }^{[24]}$ These amends provided safeguards against arbitrary rise in charges from the accredited facilities. To deal with fraudulent claims, amends on modes of keeping records from manual to computerised were put to place. ${ }^{[28]}$ Also amended were the value of the stamp attached to the NHIF card to conform with the latest contribution rates. Review of daily charges for services by accredited healthcare facilities were significant in ensuring that charges commensurate with quality received. The Investment Committee of the NHIF Advisory Council advised on the best financial strategies of increasing investment and revenue collection policies. ${ }^{[24]}$ This amendment was relevant in enhancing efficiency of services and lobbying for expanded resource allocation to the healthcare sector. Subsequently, the amendments were assented to by the president effected as NHIF Amendment Act Number 4 of 1972 on 1 July 1972. ${ }^{\text {[27] }}$

\section{REFERENCES}

[1] Republic of Kenya (1964), Development Plan, 1964 -1970 Nairobi: Government Printers

[2] Republic of Kenya (1965), African Socialism and Its Application in Kenya Nairobi: Government Printers

[3] Republic of Kenya (1965), National Health Services Scheme, 1965-1966 Nairobi: Government Printers

[4] Republic of Kenya (1966), Legislation, Acts and National Health Services Act, 1966 Nairobi: Government Printers

[5] Republic of Kenya (1966), Ministry of Local Government, Housing and Health: Establishment of a Board of Management, 1966 Nairobi: Government Printers 
[6] Republic of Kenya (1966), National Health Insurance Services Nairobi: Government Printers

[7] Republic of Kenya (1966), National Hospital Insurance Fund: Advisory Council, 1966 Nairobi: Government Printers

[8] Republic of Kenya (1966), Insurance and Compensation Schemes, 1966 Nairobi: Government Printers

[9] Republic of Kenya (1966), Central Authority, 1966- 1968 Nairobi: Government Printers

[10] Republic of Kenya (1967), African Research Foundation, Survey on Health Policy in Kenya Nairobi: Government Printers

[11] Republic of Kenya (1967), National Hospital Insurance Advisory Council, 1967 Nairobi: Government Printers

[12] Republic of Kenya (1967), National Hospital Insurance Fund: Compulsory Benefits, 1967 Nairobi: Government Printers

[13] Republic of Kenya (1967), Ministry of Local Government, Housing and Health: Formation of NHIF Advisory Council, 1967 Nairobi: Government Printers

[14] Republic of Kenya (1968), Insurance and Compensation Schemes General, 1968 Nairobi: Government Printers

[15] Republic of Kenya (1968), Insurance and Compensation Scheme: NHIF, 1968 Nairobi: Government Printers

[16] Republic of Kenya (1968), National Hospital Insurance Fund: Compulsory Benefits, 1968 Nairobi: Government Printers

[17] Republic of Kenya (1969), National Hospital Insurance Fund: Advisory Council, 1969 Nairobi: Government Printers

[18] Republic of Kenya (1969), Workmen's Compensation Act, 1969 Nairobi: Government Printers

[19] Republic of Kenya (1969), Ministry of Local Government, Housing and Health: NHIF Board of Management, 1969 Nairobi: Government Printers

[20] Republic of Kenya (1969), Central Authority, 1969 Nairobi: Government Printers

[21] Republic of Kenya (1969), Ministry of Local Government, Housing and Health: NHIF Advisory Council, 1969 Nairobi: Government printers

[22] Republic of Kenya (1969), NHIF: Compulsory Benefits, 1969 Nairobi: Government Printers

[23] Republic of Kenya (1970), NHIF: Compulsory Benefits, 1970-1972 Nairobi: Government Printers

[24] Republic of Kenya (1970), Central Authority, 1970-1972 Nairobi: Government Printers

[25] Republic of Kenya (1970), World Bank Report, 1970-1974 Nairobi: Government Printers

[26] Republic of Kenya (1970), NHIF Advisory Council, 1970 Nairobi: Government Printers

[27] Republic of Kenya (1972), NHIF: Amendments, 1972 Nairobi: Government Printers

[28] Republic of Kenya (1972), NHIF: Board of Management and Amendments, 1972 Nairobi: Government Printers

[29] Republic of Kenya (1972), National Hospital Insurance Fund: Compulsory Benefits, 1972 Nairobi: Government Printers

[30] Republic of Kenya (1973), Central Authority, 1973-1977, Nairobi: Government Printers

[31] Caporaso, James and David Levine (1992), Theories of Political Economy New York: Cambridge University Press

[32] Cohen, Benjamin (2008), International Political Economy: An Intellectual History Princeton: Princeton University Press

[33] Gesami, Racheal (2000), "Healthcare Financing in Kenya: An Empirical Analysis" Unpublished Ph.D. Dissertation, University of Nairobi

[34] Gilpin, Robert (2001), Political Economy: Understanding the International Economic Order London: Oxford University Press

[35] Groewegen, Peter (2008), Political Economy and Economics, vol. 3 Oxford: Palgrave

[36] Mwabu, Germano, Joseph Wang'ombe and Tania Zaman (2004), "Introduction" in G. Mwabu et al (eds.) Improving Health Policy in Africa Nairobi: University of Nairobi Press

[37] Weingst, Barry and Donald Wittmann (eds.) (2008), The Oxford Handbook of Political Economy Oxford: Oxford University Press

[38] Kiprop, Dinah, Oral Interview, Nairobi, 30/08/2019

[39] Kuria, Joe, Oral Interview, Nakuru, 24/09/2019

[40] Mabonga, Rebecca, Oral Interview, Nakuru, 16/09/2019

[41] Njoroge, Joe, Oral Interview, Nairobi, 24/09/2019

[42] Ominde, Frank, Oral Interview, Nakuru, 16/09/2019
PROFILE

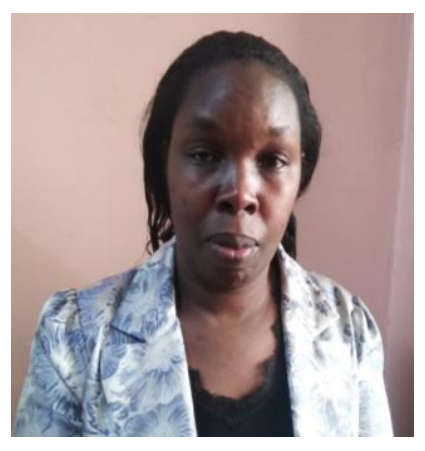

M.A (HIST) 2004-2012: Title of the thesis: Impact of Colonialism on Disease Spread Among the Kipsigis of Kenya, 1895-1963.

PHD (HIST) 2015- on Going: Title of The Thesis: Political Economy of The Social Health Insurance: the case of the National Hospital Insurance Fund, 1966-2016, Department of Philosophy, History and Religion, Egerton University Lecturer of History Department of Education, School of Education and Arts, Great Lakes University of Kisumu 